\title{
Optimasi Karbopol dan Gliserin pada Sediaan Gel Dispersi Padat Ibuprofen Secara Simplex Lattice Design
}

\section{Optimization of Carbopol and Glycerin in Solid Dispersion Gel of Ibuprofen by Simplex Lattice Design}

\author{
Rochmadani Wahyu Aji Pangestu ${ }^{1}$, Siti Aisiyah ${ }^{1}$, Nuraini Harmastuti ${ }^{1}$ \\ rochmadaniwahyu@gmail.com \\ ${ }^{1}$ S1 Farmasi, Universitas Setia Budi, Surakarta \\ Riwayat Artikel: Dikirim Juli 2020; Diterima September 2020; Diterbitkan Oktober 2020
}

\begin{abstract}
Abstrak
Ibuprofen merupakan obat golongan Non Steroid AntiInflamantory Drug (NSAID) yang berfungsi sebagai pengobatan nyeri atau inflamasi. Ibuprofen adalah obat golongan Biopharmaceutical Classification System (BCS) kelas II dengan karakteristik kelarutan rendah dan permeabilitasnya tinggi. Dispersi padat dapat meningkatkan kelarutan. Ibuprofen memiliki berbagai efek samping sehingga perlu dibuat rute lain yaitu sediaan topikal. Penelitian ini dilakukan untuk mengetahui pengaruh kombinasi karbopol sebagai basis gel dan gliserin sebagai senyawa peningkat penetrasi terhadap mutu fisik dan pelepasan zat aktifnya serta untuk menentukan formula paling optimum. Penelitian ini menggunakan metode simplex lattice design dengan 2 faktor yakni karbopol dan gliserin pada formula 1 ; formula 2 ; formula 3 secara berurutan 100\%:0\% ; 50\%:50\% ; 0\%:100\%. Pembuatan dispersi padat dengan metode peleburan, kemudian dilakukan uji FTIR lalu dibuat sediaan gel dispersi padat ibuprofen-PEG 6000. Uji pelepasan zat dilakukan dengan menggunakan alat sel difusi franz dengan membran selofan, kemudian dilakukan penentuan formula optimum berdasarkan counterplot yang diperoleh dari Design Expert 10.0.1 trial version dengan parameter titik kritis daya lekat, viskositas dan penetrasi zat. Hasil penelitian menunjukan bahwa karbopol dan gliserin mempengaruhi mutu fisik dan pelepasan obat dalam sediaan gel. Gliserin lebih mempengaruhi pelepasan obat. Proporsi karbopol $1,011 \%$ dan gliserin $7,489 \%$ menghasilkan formula optimum dengan mutu fisik dan pelepasan obat paling baik.
\end{abstract}

Kata kunci: Dispersi padat, gel, ibuprofen, optimasi, simplex lattice design

\begin{abstract}
Ibuprofen is a part of the Non Steroid Anti-Inflamatory Drug (NSAID) that serves as the treatment of pain or inflammation. Ibuprofen is a part of biopharmaceutical classification system (BCS) class II drug with the characteristics of low solubility and high permeability. Solid dispersion may increase solubility. Ibuprofen has a variety of side effects so it need to be made into other routes of administration such as topical. This study was conducted to understand the effect of combinations of carbopol as the gelling agent and glycerin as a penetration enhancer compound to the physical quality and the
\end{abstract}


release of active substances also to determine the optimum formula. This study used simplex lattice design method with two factors which is carbopol and glycerin in formula 1 ; formula 2 ; formula 3 in sequence 100\%:0\% ; 50\%:50\% ; 0\%:100\%. The solid dispersion was made by the melting method, then was tested with FTIR and then was made into a solid dispersion gel of ibuprofen-PEG 6000. The release of substance was tested using franz diffusion cell through a cellophane membrane, then the optimum formula was determined based on the counterplot from Design Expert 10.0.1 trial version with critical parameters of adhesion, viscosity, and penetration of substance. The result of the study showed that carbopol and glycerin affecting the physical quality and the release of a drug in a gel. Glycerin has more impact to the release of the drug. The proportion of carbopol 1,011\% and glycerin $7,389 \%$ produce the optimum formula with the most excellent physical quality and the release of the drug.

Key word: Gel, ibuprofen, optimization, simplex lattice design, solid dispersion

\section{Pendahuluan}

Ibuprofen merupakan obat golongan Non Steroid Anti-Inflamatory Drug (NSAID) tidak selektif turunan asam propionate, salah satu fungsinya sebagai pengobatan nyeri dan inflamasi yang disebabkan beberapa kondisi yaitu Rheumatoid Arthritis dan Osteoarthritis (Garzon dan Martinez 2004).Ibuprofen jika dikonsumsi secara terus menerus dalam jangka waktu yang lama dapat menimbulkan efek samping seperti gangguan gastrointestinal, dyspepsia, diare, infeksi saluran cerna atas, mual, dan kembung (Rainsford et al 2003). Sediaan topikal merupakan salah satu rute lain yang dapat digunakan untuk menghindari efek samping yang ditimbulkan oleh obat ibuprofen. Sediaan transdermal dapat menanggulangi efek samping tersebut karena sediaan transdermal tidak mengalami first past metabolism di hati dan memberikan penghantaran yang konsisten pada jangka waktu yang lama (Prausnitz dan Langer 2008). Gel adalah salah satu sediaan transdermal yang dapat digunakan untuk penghanataran obat. Gel adalah sediaan semipadat berupa suspensi dan partikel anorganik kecil atau molekul organik besar yang terpenetrasi di dalam suatu cairan (Escobar et al 2006). Gel memiliki konsentrasi air yang lebih banyak dibandingkan sediaan topikal lain seperti krim dan salep, sehingga penyerapan pada kulit lebih baik serta memberikan rasa dingin pada kulit, cepat mengering sehingga mudah dicuci, memiliki penetrasi yang baik pada kulit dengan mekanisme menghidrasi stratum korneum, mudah dioleskan, lembut, dan tidak lengket pada kulit (Voigt 1995).

Gelling agent dan senyawa peningkat penetrasi adalah salah satu komponen penting dalam sediaan gel. Gelling agent yang digunakan pada penelitian ini adalah karbopol. Karbopol adalah salah satu kelompok polimer akrilat yang berikatan silang dengan polialkenil eter (Rowe et al 2009). Karbopol pada sediaan gel akan berpengaruh terhadap vikositas, viskositas juga berpengaruh terhadap laju penyerapan obat, semakin kental maka akan semakin lama penyerapan obatnya begitu pula sebaliknya. Keuntungan dari penggunaan basis karbopol yaitu lebih kompatibel dengan beberapa bahan aktif, interval viskositas yang lebar, mempunyai viskositas yang tinggi pada konsentrasi rendah, dan mempunyai karakteristik organoleptis yang baik (Islam et al 2004). Karbopol juga mudah terdispersi dalam air dan dalam konsentrasi kecil dapat berfungsi sebagai basis gel dengan kekentalan yang cukup. Karbopol dapat membentuk konsistensi gel ketika digunakan pada konsentrasi 0,5\%-2\% (Rowe et al 2009).

\section{Metode Penelitian}

Penelitian ini bersifat ekperimental laboratorik. Tahapan yang dilakukan pada penelitian adalah pembuatan dispersi padat ibuprofen-PEG 6000 (1:1,5), penetapan kadar $\%$ recovery ibuprofen, pembuatan gel, pengujian sifat fisik gel, dan uji penetrasi iburprofen. 


\section{Alat}

Alat yang digunakan dalam penelitian ini adalah Spektrofotometer UV-Vis, disolusi tipe 1, spektroskopi FTIR IRPrestige-21, Honson Horizontal Diffusion Cell System Digital (IKA, Jerman), magnetic stirrer, timbangan digital, alat uji homogenitas, viskotester, $\mathrm{pH}$, daya sebar, daya lekat, sudip, stopwatch, viskometer, $\mathrm{pH}$ meter, mortir, stamper dan berbagai peralatan gelas.

\section{Bahan}

Bahan yang digunakan dalam penelitian ini adalah ibuprofen, karbopol, gliserin, PEG 6000, TEA, dapar fosfat $\mathrm{pH} 7,4$, aquades, membran selofan.

\section{Tahapan Penelitian}

\section{Pembuatan Dispersi padat}

Pembuatan dispersi padat dilakukan dengan perbandingan ibuprofen-PEG 60001 : 1,5. Bahan ibuprofen dan PEG 6000 ditimbang sesuai dengan formulasi. Melakukan peleburan pada suhu $80^{\circ} \mathrm{C}$ di atas water bath. PEG dimasukan ke dalam cawan yang diletakkan di atas water bath sampai melebur sempurna, lalu ditambahkan ibuprofen sedikit demi sedikit dan lalu diaduk sampai homogen. Leburan didinginkan pada ice bath lalu disimpan dalam desikator selama 24-48 jam sebelum dihaluskan menggunakan mortir dan stamper. Setelah itu ayak menggunakan ayakan no. 80 .

\section{Uji FTIR}

Pemeriksaan ibuprofen yang terdispersi PEG 6000 dilakukan dengan mencampurkan ibuprofen yang terdispersi dengan PEG 6000 dengan KBr. Perbandingan yang digunakan sebesar $3 \mathrm{mg}$ ibuprofen yang terdispersi PEG 6000 dengan 300 mg KBr.
Kemudian meletakkan hasil campuran ke dalam alat pompa hidrolik. Tekan dengan tekanan 3 ton sehingga terbentuk pellet. Melakukan analisis pellet menggunakan alat spektroskopi FTIR. Hasil spektra sampel dibandingkan dengan spektra murni ibuprofen dan PEG.

\section{Penentuan \% Recovery Ibuprofen}

Dosis ibuprofen dalam sediaan topikal yaitu $1 \%$ sehingga perlu dilakukan penetapan kadar dispersi padat setara 1\% ibuprofen (Lakhsmi et al 2011). Penetapan kadar ibuprofen dalam dispersi padat ibuprofen-PEG 6000 ditentukan menggunakan metode spektrofotometri UV-Vis. Ditimbang dispersi padat ibuprofen dan dilarutkan dengan $\mathrm{NaOH}$. Larutan dispersi padat Ibuprofen-PEG 6000 yang sudah diencerkan diamati serapannya dengan spektrofotometri UV-Vis pada panjang gelombang maksimum yang terpilih. Kadar yang diperoleh lalu dibandingkan dengan kadar hasil teoritis untuk megetahui \% recovery Ibuprofen dalam dispersi padat IbuprofenPEG 6000. Replikasi dilakukan sebanyak 3 kali kemudian dihitung koefisien variasi (CV) dari hasil tersebut.

\section{Pembuatan Gel}

Pembuatan gel dispersi padat ibuprofen-PEG 6000 dilakukan dengan cara mendispersikan basis karbopol ke dalam akuades bebas $\mathrm{CO}_{2}$ dan diberi TEA. Setelah terbentuk basis gel yang baik kemudian dicampurkan secara bertahap dengan larutan dispersi padat yang terdiri dari propilen glikol, gliserin, dan air. Masing-masing karbopol dan gliserin dilakukan dengan 3 konsentrasi berbeda. Rancangan formula dapat dilihat pada tabel I.

Tabel I. Formula gel dispersi padat ibuprofen-PEG 6000

\begin{tabular}{ccccc}
\hline Bahan & Fungsi & Formula & Formula & Formula \\
& & $1(\%)$ & $2(\%)$ & $3(\%)$ \\
\hline Dispersi padat & Bahan aktif & $2,75^{*}$ & $2,75^{*}$ & $2,75^{*}$ \\
Ibuprofen-PEG 6000 & Gelling agent & 0,5 & 1,5 & 2,5 \\
Karbopol & Penetration enhancer & 8 & 7 & 6 \\
Gliserin & Kosolven & 20 & 20 & 20 \\
Propilen Glikol & Alkalizing agent & 2 & 2 & 2 \\
TEA & & 100 & 100 & 100 \\
Aquades ad & &
\end{tabular}




\section{Evaluasi Sediaan Gel}

Evaluasi sediaan gel meliputi pengamatan organoleptis, pengujian $\mathrm{pH}$, pengujian viskositas, pengujian daya sebar, pengujian daya lekat dan pengujian stabilitas. Hasil pengujian laju pelepasan obat menggunakan alat Honson Horizontal Diffusion Cell System Digital, analisis formula optimum secara simplex lattice design. Pengujian organoleptis berupa pengamatan terhadap bentuk, warna, dan aroma gel yang dihasilkan.

Pengujian $\mathrm{pH}$ dilakukan menggunakan $\mathrm{pH}$ meter digital. Persyaratan $\mathrm{pH}$ sediaan gel yang dapat ditoleransi untuk tidak mengiritas kulit yaitu 4,5-6,5 (Naibaho 2013). Viskositas sediaan gel diuji menggunakan alat viskometer pada suhu ruang. Nilai visositas (dPa's) dapat dibaca dari skala rotor.

Pengujian daya sebar sebanyak 0,5 gram sampel diletakkan pada pusat antara dua lempeng gelas kaca berskala dan diletakkan beban dengan berat $50 \mathrm{~g}$ dengan interval 1 menit lalu diukur diameter dari 4 sisi, kemudian berat ditambah menjadi $100 \mathrm{~g}$ dan $150 \mathrm{~g}$ masing-masing dengan interval yang sama.

Pengujian daya lekat sebanyak 0,5 gram sediaan di atas gelas obyek, kemudian diletakkan gelas obyek yang lain pada bagian atas sediaan tersebut, kemudian ditekan dengan beban $1 \mathrm{~kg}$ selama 5 menit. Gelas obyek tersebut dipasang alat uji kemudian diberi beban seberat 80 gram dan dicatat waktu hingga kedua gelas obyek terpisah (Azkiya et al 2017).

Uji stabilitas dilakukan dengan metode cycling test yaitu dengan menyimpan sediaan pada suhu $4 \pm 2^{\circ} \mathrm{C}$ selama 24 jam kemudian dipindahkan ke suhu $40 \pm 2^{\circ} \mathrm{C}$ selama 24 jam (1 siklus). Setelah itu dilanjutkan sampai lima siklus. Pada siklus terakhir, dilihat ada tidaknya pemisahan fase atau perubahan secara fisik, uji $\mathrm{pH}$ dan uji viskositas sediaan (Sharon et al 2013).

Pengujian laju pelepasan obat in vitro gel dilakukan dengan cara pada bagian kompartemen reseptor diisi dengan dapar fosfat $\mathrm{pH} 7,4$ dan dijaga suhu $37 \pm 0,5^{\circ} \mathrm{C}$, serta diaduk menggunakan magnetic stirrer $100 \mathrm{rpm}$. Membran selofan diletakkan di antara kompartemen donor dan kompartemen reseptor. Formula gel dispersi padat ibuprofenPEG 6000 sejumlah $2 \mathrm{~g}$ diaplikasikan pada permukaan membran. Pengambilan larutan sampel sebanyak $3 \mathrm{~mL}$ pada menit ke-5, 10, 15, 30, 45, 60, dan 90 dari kompartemen reseptor menggunakan pipet mikro dan segera digantikan dengan dapar fosfat $\mathrm{pH} \quad 7,4$ sejumlah voume yang sama. Larutan sampel selanjutnya dibaca serapan menggunakan spektofotometri UV-Vis pada panjang gelombang maksimum menggunakan blanko dapar fosfat $\mathrm{pH} 7,4$. Berdasarkan data serapan yang diperoleh, kemudian dilakukan perhitungan jumlah kumulatif ibuprofen yang tertranspor melewati membran selofan.

Penentuan formula optimum gel dispersi pada ibuprofen-PEG 6000 dengan menggunakan parameter daya lekat, viskositas, dan laju penetrasi zat dengan melihat nilai fluks masing-masing diberi kriteria yang sesuai dengan besarnya pengaruh terhadap gel menggunakan persamaan simplex lattice design $(\mathrm{Y}=\mathrm{B} 1(\mathrm{~A})+\mathrm{B} 2+\mathrm{B} 12(\mathrm{~A})(\mathrm{B})) \cdot$ Penentuan formula optimum dengan menggabungkan counter plot pada masing-masing parameter menggunakan program Design Expert ${ }^{\circledR}$ 10.0.1 trial.

\section{Hasil Dan Pembahasan \\ Pemeriksaan Dispersi Padat Ibuprofen dengan FTIR}

Berdasarkan hasil scanning IR yang dilakukan menunjukkan adanya perbedaan serapan amtara serapan ibuprofen murni dengan serapan ibuprofen setelah dilakukan proses dispersi dengan PEG 6000. Pada dispersi padat menunjukan karakteristik puncak IR pada C-H stretching 2954,95 ; $\mathrm{COOH} 1720,50 ; \mathrm{C}=\mathrm{C}$ aromatis 1465,$90 ; \mathrm{C}-\mathrm{O}$ stretching 1112,93. Hasil serapan FTIR dapat dilihat pada tabel II.

Tabel II. Pemeriksaan gugus fungsi FTIR

\begin{tabular}{cccc}
\hline $\begin{array}{c}\text { Gugus } \\
\text { fungsi }\end{array}$ & $\begin{array}{c}\text { Ibuprofen } \\
\left(\mathbf{c m}^{-1}\right)\end{array}$ & $\begin{array}{c}\text { PEG } \\
\mathbf{6 0 0 0} \\
\left(\mathbf{c m}^{-1}\right)\end{array}$ & $\begin{array}{c}\text { Dispersi } \\
\text { ibuprofen } \\
\left.\mathbf{( c m}^{-1}\right)\end{array}$ \\
\hline C-H & 2954,95 & 2883,58 & 2954,95 \\
stretching & & & 2875,86 \\
COOH & 1720,50 & & 1720,50 \\
C=C & 1462,04 & & 1465,90 \\
aromatis & & 1145,72 & 1147,65 \\
C-O & & 1109,07 & 1112,93 \\
stretching & & & \\
\hline
\end{tabular}


Gugus khas pada PEG 6000 yaitu C-H stretching terjadi pergeseran bilangan gelombang dari $2883,58 \mathrm{~cm}-1$ menjadi 2875,95 $\mathrm{cm}-1$. C-O stretching juga mengalami pergeseran bilangan gelombang dari 1145,72 ; 1109,07 menjadi 1147,65; 1112,93. Pergeseran bilangan gelombang antara puncak PEG 6000 murni dengan puncak dispersi padat menandakan adanya interaksi dan terjadinya ikatan hidrogen atau ikatan van der waals. Pergeseran bilangan gelombang diduga terjadi karena adanya ikatan hidrogen antara dua komponen.

\section{Penetapan Kadar Dispersi Padat}

Sampel dispersi padat ibuprofen-PEG 6000 dibaca dengan menggunakan spektrofotometri UV-Vis pada panjang gelombang $264 \mathrm{~nm}$ dilakukan sebanyak 3 replikasi. Hasil absorbansi kemudian dimasukkan kedalam kurva kalibrasi untunk mengetahui kadar ibuprofen murni dengan menghitung nilai $\mathrm{CV}$. Hasil rata-rata \%recovery ibuprofen dengan pembawa PEG 6000 sebesar $90,77 \% \pm 1,396$. Hasil \%recovery dapat dilihat pada tabel III.

Tabel III. Hasil \%recovery dispersi padat ibuprofen

\begin{tabular}{|c|c|c|c|c|c|c|}
\hline Replikasi & Absorbansi & $\begin{array}{c}\text { Kadar } \\
\text { ibuprofen } \\
\text { penelitian } \\
\text { (ppm) }\end{array}$ & $\begin{array}{c}\text { Kadar } \\
\text { ibuprofen } \\
\text { teoritis (ppm) }\end{array}$ & $\%$ Recovery & $\begin{array}{l}\text { Kadar } \\
\text { rata-rata } \\
\pm \mathrm{SD}\end{array}$ & $\mathrm{CV}$ \\
\hline 1 & 0,231 & 109,5 & 120,4 & 90,98 & \multirow{3}{*}{$\begin{array}{c}90,77 \pm \\
1,396\end{array}$} & \multirow{3}{*}{$1,53 \%$} \\
\hline 2 & 0,226 & 106,78 & 119,6 & 89,28 & & \\
\hline 3 & 0,242 & 115,61 & 125,6 & 92,02 & & \\
\hline \multicolumn{7}{|c|}{ Tabel IV. Hasil uji mutu fisik gel ibuprofen } \\
\hline \multirow{2}{*}{\multicolumn{3}{|c|}{ Parameter }} & & Formula & & \\
\hline & & & I & II & \multicolumn{2}{|c|}{ III } \\
\hline \multirow{3}{*}{\multicolumn{2}{|c|}{ Organoleptis }} & Bentuk & Gel & Gel & \multicolumn{2}{|c|}{ Gel } \\
\hline & & Warna & Putih & Putih & \multicolumn{2}{|c|}{ Putih } \\
\hline & & Bau & Tidak berbau & Tidak berbau & \multicolumn{2}{|c|}{ Tidak berbau } \\
\hline \multicolumn{3}{|c|}{ Homogenitas } & Homogen & Homogen & \multicolumn{2}{|c|}{ Homogen } \\
\hline \multicolumn{3}{|c|}{$\mathrm{pH}$} & 5,93 & 4,76 & \multicolumn{2}{|c|}{4,48} \\
\hline \multicolumn{3}{|c|}{ Viskositas (dPa's) } & 27 & 240 & \multicolumn{2}{|c|}{340} \\
\hline \multicolumn{3}{|c|}{ Daya sebar $150 \mathrm{~g}(\mathrm{~cm})$} & 8,01 & 5,12 & \multicolumn{2}{|c|}{4,02} \\
\hline \multicolumn{3}{|c|}{ Daya lekat (detik) } & 0,76 & 0,80 & \multicolumn{2}{|c|}{0,94} \\
\hline
\end{tabular}

\footnotetext{
Keterangan:

Formula I : : Karbopol 0,5\% : Gliserin 8\%

Formula II : Karbopol 1,5\%: Gliserin 7\%

Formula III : Karbopol 2,5\% : Gliserin 6\%
}

\section{Hasil Pengujian Mutu Fisik Gel Ibuprofen}

Uji mutu fisik gel ibuprofen melibuti penguiian organoleptis gel, homogenitas, $\mathrm{pH}$, daya sebar, dan daya lekat. Hasil dapat dilihat pada tabel IV. Berdasarkan hasil pengamatan organoleptis diketahui bahwa semua gel memiliki bentul, warna dan bau yang sama yakni berbentuk gel, berwarna putih dan tidak berbau.

Hasil uji homogentias gel menunjukkan ketiga formula memiliki homogentias yang baik, karena tidak terdapat partikel atau zat yang belum tercampur secara homogen pada basisnya, hasil telah menunjukkan zat aktif sudah terdistribusi secara merata didalam sediaan.
Berdasarkan hasil pengamatan diketahui bahwa setiap formula memiliki $\mathrm{pH}$ yang berbeda pada masing-masing sediaan gel. Pada formula 1 memiliki $\mathrm{pH}$ yang lebih tinggi dibanding formula lainnya, komposisi dari gelling agent dan senyawa peningkat penetrasi yang bervariasi ternyata mempengaruhi hasil $\mathrm{pH}$ setiap sediaan. Dari data hasil uji $\mathrm{pH}$ dapat diketahui sediaan memasuki kriteria rentang $\mathrm{pH}$ yang dapat di toleransi untuk tidak mengiritasi kulit yaitu 4,5-6,5 (Naibaho 2013).

Pengujian viskositas untuk mengetahui viskositas sediaan gel dan pengaruh variasi konsentrasi gelling agent pada sediaan gel yang dihasilkan. Hasil menunjukan konsentrasi gelling agent berbanding lurus dengan hasil vikositas. 
Semakin besar konsentrasi yang digunakan maka viskositas semakin besar begitu pula sebaliknya.

Pengujian daya sebar gel diperlihatkan oleh diameter sebar gel terhadap beban yang ditambah secara berkala hingga dihasilkan diameter yang konstan. Pengujian dilakukan sampai pembebanan 150 gram. Diameter sebar yang diinginkan menurut literatur berkisar 3-7 cm (Nurahmanto 2017). Hasil pengujian menunjukkan formula 1 memiliki hasil lebih dari rentang yang dapat diterima dikarenakan sifat fisik gel yang encer dan memiliki viskositas yang sangat kecil.

Pengujian daya lekat untuk mengetahui daya lekat sediaan gel dan pengaruh variasi konsentrasi gelling agent dan senyawa peningkat konsentrasi yang digunakan pada sediaan gel dispersi padat ibuprofen. Uji daya lekat menunjukan waktu yang diperlukan oleh suatu sediaan gel melekat pada kulit, dimana semakin besar daya lekat maka waktu kontak gel dengan kulit semakin lama yang menyebabkan absorbsi obat melalui kulit akan semakin besar serta penghantaran obat menjadi semakin efektif.

\section{Pengujian Laju Penetrasi}

Uji penetrasi dilakukan dengan menggunakan sel difusi Franz horizontal. Uji penetrasi dilakukan untuk mengetahui jumlah ibuprofen yang tertranspor ke kompartemen reseptor melalui membran. Membran yang digunakan yaitu membran sintetik selofan. Pada kompartemen reseptor diisi dengan dapar fosfat $\mathrm{pH} 7,4$ karena sesuai dengan kondisi $\mathrm{pH}$ biologis manusia. Jumlah kumulatif gel dispersi padat ibuprofen yang terpenetrasi dapat dilihat pada gambar 1.

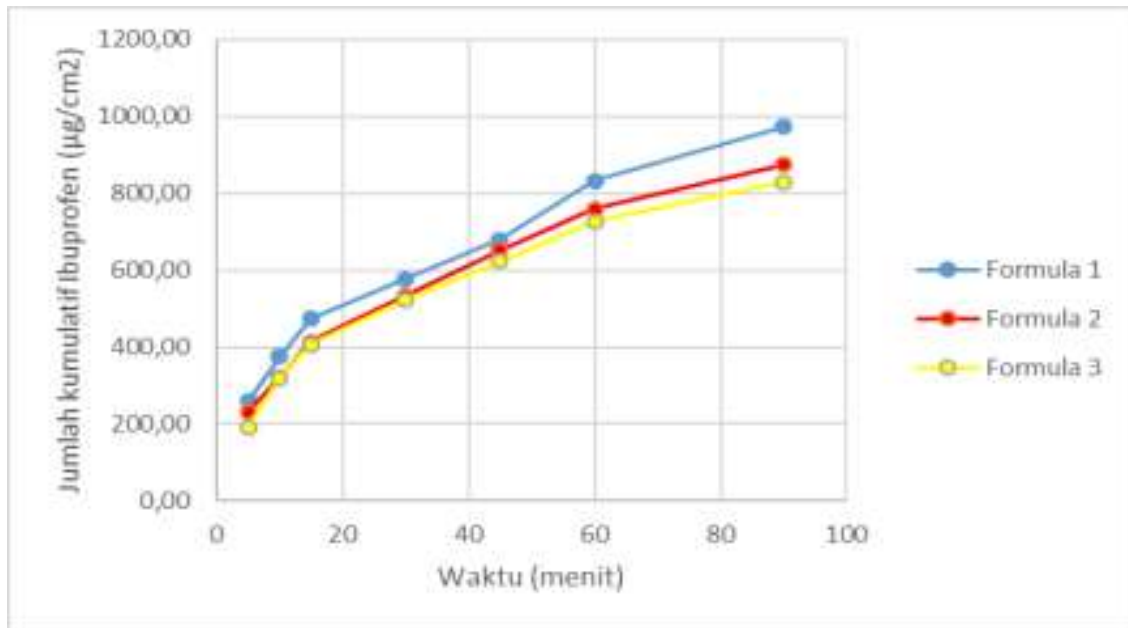

Gambar 1. Profil jumlah kumulatif ibuprofen yang terpenetras

Keterangan Gambar 1:

Formula 1: Viskositas gel 27 dPa's dengan karbopol 0,5\% dan enhancer gliserin 8\%

Formula 2: Viskositas gel $240 \mathrm{dPa}$ 's dengan karbopol 1,5\% dan enhancer gliserin 7\%

Formula 3: Viskositas gel $340 \mathrm{dPa}$ 's dengan karbopol 2,5\% dan enhancer gliserin 6\%

Berdasarkan gambar diatas dapat diketahui dengan meningkatnya waktu maka jumlah ibuprofen yang tertranspor semakin meningkat. Pada menit ke-90 yang merupakan menit terakhir pengujian, jumlah ibuprofen yang tertranspor pada F1, F2, dan F3 yaitu $973,32 \mu \mathrm{g} / \mathrm{cm}^{2}, 875,03 \mu \mathrm{g} / \mathrm{cm}^{2}$, dan 829,20 $\mu \mathrm{g} / \mathrm{cm}^{2}$.
Penentuan Formula Optimum

Penentuan formula optimum dilakukan dengan aplikasi Design Expert 10.0.1 trial secara Simplex Lattice Design. Penelitian ini mengoptimasi gelling agent yaitu karbopol dan senyawa peningkat penetrasi yaitu gliserin. Penentuan formula optimum diuji dengan 3 parameter sebagai titik kritis optimasi yang merupakan viskositas, daya lekat, dan penetrasi zat.

Hasil pengujian viskositas yang dilakukan pendekatan secara simplex lattice design didapat persamaan sebagai berikut:

Viskositas $=340(\mathrm{~A})+27$ (B) +226 (A)(B)...(1)

Keterangan:
(A) : Proporsi Karbopol
(B) : Proporsi Gliserin 

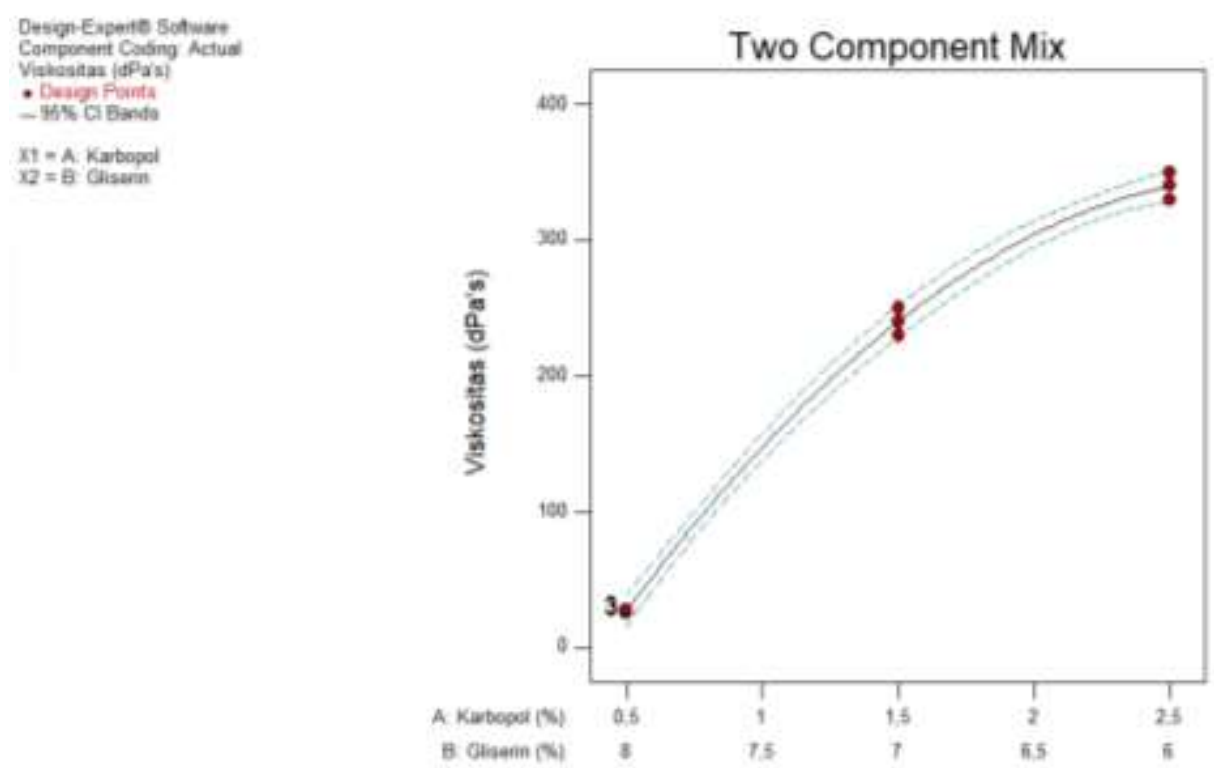

Gambar 2. Kurva viskositas berdasarkan simplex lattice design

Dari persamaan di atas diketahui bahwa peningkatan nilai viskositas lebih besar dipengaruhi oleh proporsi karbopol (koefisien 340) dibandingan dengan gliserin (koefisien 27). Adanya interaksi antara kedua bahan formula ini mampu meningkatkan pula nilai viskositasnya (koefisien 226). Pengaruh karbopol memiliki nilai koefisien lebih besar karena merupakan gelling agent yang dimana menentukan kekentalan suatu sediaan gel.
Hasil pengujian daya lekat yang dilakukan pendekatan secara simplex lattice design didapat persamaan sebagai berikut:
Daya
lekat
$=$

$0,62(\mathrm{~B})$

Keterangan:
(A) : Proporsi Karbopol
(B) : Proporsi Gliserin
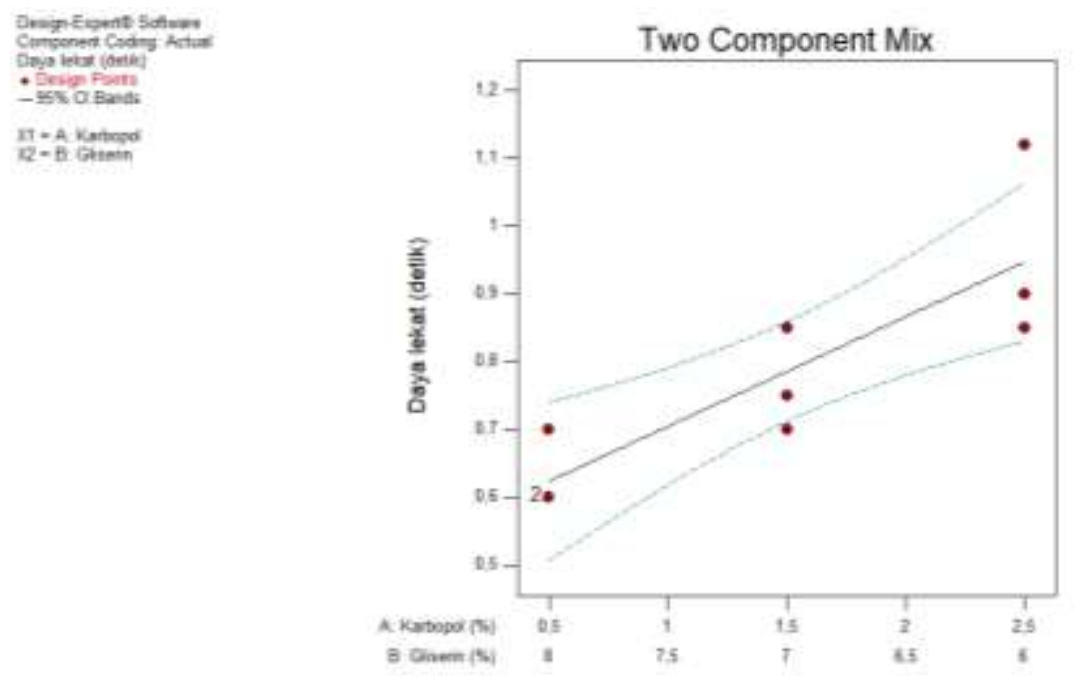

Gambar 3. Kurva daya lekat berdasarkan simplex lattice design 
Optimasi Karbopol dan Gliserin pada Sediaan Gel Dispersi Padat Ibuprofen Secara Simplex Lattice Design

Dari persamaan di atas diketahui bahwa peningkatan daya lekat lebih dipengaruhi oleh proporsi karbopol dengan koefisien 0,95 dibandingan dengan gliserin (koefisien 0,62). Pencampuran keduanya ternyata tidak terjadi interaksi yang mempengaruhi daya lekat (koefisien 0).

Dari pengujian difusi franz didapat nilai fluks penetrasi yang berasal dari nilai slope antara menit dan jumlah kumulatif ibuprofen yang tertranspor. Dari nilai fluks penetrasi kemudian dilakukan pendekatan secara simplex lattice design sehingga diperoleh sebuah persamaan:

Fluks penetrasi $=6,80(\mathrm{~A})+$ 8,14(B)..........(3)

Keterangan:
(A) : Proporsi Karbopol
(B) : Proporsi Gliserin

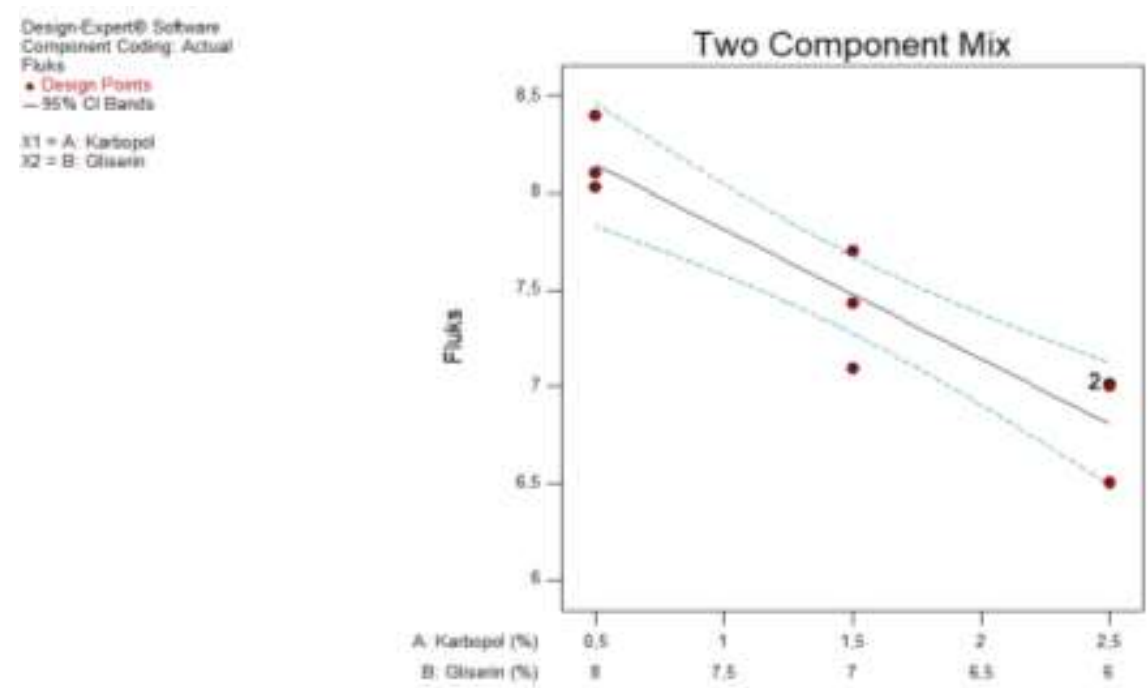

Gambar 4. Kurva fuks penetrasi berdasarkan simplex lattice design

Persamaan fluks penetrasi di atas menunjukan bahwa gliserin mampu meningkatkan fluks penetrasi dengan koefisien 8,14 begitu pula dengan karbopol (koefisien 6,80). Pencampuran antara keduanya ternyata tidak terjadi interaksi yang mempengaruhi fluks penetrasi (koefisien 0). Gliserin disini lebih mempengaruhi nilai fluks penetrasi dibandingan dengan karbopol karena gliserin sendiri menurut teori dapat meningkatkan penetrasi dalam suatu sediaan gel.

\section{Optimasi}

Parameter yang digunakan sebagai titik kritis kemudian dimasukkan ke dalam program Design Expert® 10.0.1 trial dan menghasilkan sebuah persamaan simplex lattice design. Kriteria optimasi seperti tabel V dibawah ini:

Tabel V. Kriteria formula optimum

\begin{tabular}{ccccc}
\hline \multirow{2}{*}{ Parameter } & \multirow{2}{*}{ Target } & Importance & \multicolumn{2}{c}{ Limits } \\
\cline { 3 - 5 } & & & Lower & Upper \\
\hline Viskositas & In target & ++ & $26 \mathrm{dPa}$ 's & $350 \mathrm{dPa}$ 's \\
\hline Daya lekat & Maximize & ++ & 0,6 detik & 1,12 detik \\
\hline Fluks Penetrasi & Maximize & ++++ & 6,5 & 8,4 \\
\hline
\end{tabular}

Dari parameter yang digunakan dimana viskositas diatur menurut target yaitu diharapkan mendapat nilai viskositas $150 \mathrm{dPa}$ 's dan nilai prioritas (importance) plus 2, daya lekat diatur menurut nilai yang paling besar dengan nilai prioritas (importance) plus 2, dan nilai fluks penetrasi diharapkan mendapat hasil maksimum dengan nilai prioritas (importance) 
plus 4. Nilai importance disini dimaksudkan untuk hasil dari formula optimum kita lebih berfokus atau lebih memprioritaskan parameter mana yang kita inginkan. Dari parameter formula optimum kemudian didapat solusi formula optimum dengan nilai desirability

\section{Solutions} Number

1

$\begin{array}{ccc}\text { Karbopol } & \text { Gliserin } & \text { Viskositas } \\ 1,011 & 7,489 & 150.000\end{array}$

\section{Verifikasi Formula Optimum}

Data hasil pembuatan dan pengujian formula optimum kemudian dibandingkan dengan hasil prediksi dari aplikasi Design Expert 10.0.1 trial. Hasil praktek formula bisa dikatakan terverifikasi jika tidak terdapat perbedaan bermakna antara hasil teoritik dan hasil penelitian. Verifikasi ini dilakukan dengan cara uji statistika one sampel t-test. Untuk studi verifikasi formula optimum berdasarkan aplikasi Design Expert 10.0.1 trial secara simplex lattice design rata-rata menunjukan hasil yang sesuai antara prediksi dengan hasil praktek.

\section{Kesimpulan}

Komposisi karbopol dan gliserin yang berbeda-beda berpengaruh terhadap viskositas dan pelepasan obat pada sediaan gel dispersi padat ibuprofen dimana semakin tinggi konsentrasi karbopol maka viskositas semakin besar sedangkan gliserin dengan konsentrasi lebih tinggi maka pelepasan obat juga lebih besar.

Komposisi optimum dari sediaan gel dispersi padat ibuprofen yaitu dengan karbopol 1,011\% dan gliserin 7,489\% akan menghasilkan viskositas dan nilai fluks penetrasi paling baik.

\section{Ucapan Terimakasih}

Puji syukur kehadirat Tugan Yang Maha Esa yang telah memberikan rahmat-Nya sehingga penyusunan artikel ini dapat diselesaikan. Penulis tidak lupa mengucapkan terimakasih kepada semua dosen Program Studi S1 Farmasi Universitas Setia Budi Surakarta, dan semua pihak yang tidak mungkin disebutkan satu persatu yang telah memberikan kontribusinya dalam membantu penulis untuk menyelesaikan penelitian ini dan penulisan artikel ini. sebesar 0,557 nilai desirability menunjukan nilai dari hasil yang kita inginkan, semakin mendekati 1 maka hasil dari formula optimum semakin mendekati dari hasil formula optimum yang kita inginkan.
Daya Lekat 0,707
Fluks
7,801
Desirability 0,557

\section{Daftar Pustaka}

Azkiya Z, Ariyani H dan Nugraha TS. 2017. Evaluasi Sifat Fisik Krim Ekstrak Jahe Merah (Zingiber officinale RPsc. Var. rubrum) Sebagao Antinyeri. Journal of Current Pharmaceutical Sciences.

Escobar JJ, Cervantes ML, Kalia YN, Guerrero DQ, Quintanar AG. 2006. Applications of Thermoreversible Pluronic F-127 Gel in Pharmaceutical Formulation. J. Pharm Pharmaceut. Sci. Vol. 9 (3): 339-358.

Garzon, CL, Martinez F. 2004. Temperature Dependence of Solubility for Ibuprofen in Some Organic and Aqueous Solvents. J. Sol. Chem. Vol. 33 No. 11: 1379-1395.

Islam MT, Hornedo NR, Ciotti S, Ackermann C. 2004. Rheological Characterization of Topical Carbomer Gels Neutralized to Different pH. Pharm. Res. Vol. 21. No 7.

Lakhsmi PK, Kumar MK, Shidaran A dan Bhaskaran A. 2011. Formulation and Evaluation of Ibuprofen Topical Gel: A Novel Approach for Penetration Enhancement. Int. J. Applied Pharm. Vol 3. Issue 3. 25-30

Naibaho, Olivia H., Paulina V.Y., Yamlean, Weny Wiyono. 2013. Pengaruh basis salep terhadap formulasi sediaan salep ekstrak daun kemangi (Ocimun Sanctum L.) pada kulit punggung kelinci yang dibuat infeksi Staphyloccocus aureus. Jurnal Ilmiah Farmasi UNSRAT 2(2) ISSN 2302-2493.

Nurahmanto D, Mahrifah IR, Imaniah Azis RFN, Rosyidi VA. 2017. Formulasi Sediaan Gel Dispersi Padat Ibuprofen: Studi Gelling Agent dan Senyawa Peningkat Penetrasi. Jurnal Ilmiah Manuntung 3(1): 96-105. 
Optimasi Karbopol dan Gliserin pada Sediaan Gel Dispersi Padat Ibuprofen Secara Simplex Lattice Design

Prausnitz, MR, Langer R. 2008. Transdermal drug delivery. Nature Biotech. Vol. 26 (11): 1261-1268.

Rainsford KD, Stetsko PI, Sirko SP, dan Debski S. 2003. Gastrointestinal mucosal injury following repeated daily oral administration of conventional formulations of indometacin and other non-steroidal antiInflammatory drugs to pigs: a model for human gastrointestinal disease. J Pharm Phramacol; 55 (5): 661-668.
Rowe RC, Sheskey PJ, dan Weller PJ. 2009. Handbook of Pharmaceutical Excipients. Edisi VI. London: Publisher-Science and Practice Royal Pharmaceutical Society of Great Britain.

Voigt R. 1995. Buku Pelajaran Teknologi Farmsi Edisi V, diterjemahkan Noerono S. Yogyakarta: Gajah Mada University Press. 